\title{
単身世帯におけるライフスタイ DIVERSE LIFESTYLES AND ENERGY ルとエネルギー消費量に関する COMSUMPTION OF SINGLE-PERSON 調查 HOUSEHOLD
}

\author{
高口洋人一 $* 1$ \\ 尾崎明仁— $* 3$ \\ 広瀬拓哉— $* 2$ \\ キーワード : \\ 単身世帯，エネルギー消費量，ライフスタイル，生活モデル，多様性 \\ Keywords : \\ Single-person household, Energy consumption, Lifestyles, Pattern for living, \\ Diversity
}

\section{1. 研究背景 $\cdot$ 目的}

地球温暖化や環境問題の観点から、 $\mathrm{CO}_{2}$ 排出量・エネルギー消費量 の削減が求められている。中でも、住宅内のエネルギー消費量は、住 宅の断熱性能向上・機器の効率化にも関わらず、依然増加傾向にある。 我が国では、2005 年をピークに人口が減少し始め、世帯数も 2015 年 以降減少に転ずると予測されるが、その一方で単身世帯数は増加し続 けると予測されている ${ }^{1)}$ 。単身世帯は一人当たりのエネルギー消費量 が一般世帯に比べ 4 割程度多い2)。今後、単身世帯に対する省エネル ギー対策の重要性が高まると考えられるが、その基礎となる単身世帯 のライフスタイルに言及した文献は極めて少ない。

一方、ライフスタイルの変更に関寸る省エネルギー効果の検討例は あるものの、変更前のライフスタイルには画一的なものが多く、多様 性は考慮がなされていない3),4)。

そこで本研究では、単身世帯のライフスタイルの実態を調査した上 で、そのライフスタイルを生活行動時間・家電機器使用状況の観点か らパターン分類し、エネルギー消費量算出のためのモデルを作成する ことを目的とする。

\section{2. 単身世帯のライフスタイル実態調査}

\section{1 調査概要}

表 1 に調查概要を示す。本調査はアンケート調查 $(A$ 調查) とブロー ドバンドサービス注1) による調査 $(\mathrm{B}$ 調査)を行った。

B 調查では、回答世帯属性、生活行動時間、家電機器保有・使用状 況を調査し、 $A$ 調査では $B$ 調查の調查項目に加え、省エネルギ一意識・ 行動、年間エネルギー消費量を調查した。A 調查 96 件、B 調查 762 件 の有効回答を得て、全体では 858 件であった。ただし、年間エネルギ 一消費量に対する有効回答は A 調查の 41 件のみである。

\section{2 回答世帯属性}

$\mathrm{A}, \mathrm{B}$ 調查における回答世帯属性を図 1 に示寸。30 代以下が全体の $76 \%$ を占め、高齢者の割合は 7\%であった注2)。職業では勤め人が $63 \%$ と最も多く、次いで学生が 14\%を占める。また、B 調査は、L

Hiroto TAKAGUCHI— $* 1 \quad$ Takuya HIROSE $-* 2$
Akihito OZAKI $* 3$

We did the survey of the questionnaire of the lifestyle realities of the single-person household. Through the result, we have devised a lifestyle model of the household. This model is composed by the use frequency of home electric appliances and the daily action style. This model will become an effective model for the energy conservation adoption in thinking about the diversification of the home form in the future.

社管理の集合住宅が調查対象であり、住居形態は集合住宅が全体の $98 \%$ を占め、延床面積 $30 \mathrm{~m}^{2}$ 未満が $90 \%$ を占める結果となった。

\begin{tabular}{|c|c|c|c|}
\hline \multicolumn{2}{|r|}{ ライフスタイル実態調査 } & $\begin{array}{c}\text { アンケート調查 } \\
\text { (A調查) }\end{array}$ & $\begin{array}{c}\text { BBサービスによる調査 } \\
\text { (B調査) }\end{array}$ \\
\hline & 調査方法 & 配布回収法 & L社協力 \\
\hline & 調査期間 & 2007年7月～9月 & 2007年8月～9月 \\
\hline & 調査対象 & 学生·社会人·高齢者 & L社管理集合住宅居住世帯 \\
\hline & 調査地域 & 東京都23区 & 全国 \\
\hline \multirow{5}{*}{$\begin{array}{l}\text { 配 } \\
\text { 布 }\end{array}$} & 配布数 & 257 & - \\
\hline & 回収数 & 103 & 925 \\
\hline & \begin{tabular}{|l|l|l|l} 
収率 \\
\end{tabular} & $40 \%$ & - \\
\hline & \multirow{2}{*}{ 有効回答数 } & 96 & 762 \\
\hline & & \multicolumn{2}{|r|}{858} \\
\hline \multirow{4}{*}{ 項 } & 生活行動時間 & $\mathrm{O}$ & $\mathrm{O}$ \\
\hline & 家電機器保有·使用状況 & 0 & $\mathrm{O}$ \\
\hline & 省エネルギ一意識·行動 & $\mathrm{O}$ & $x$ \\
\hline & 年間エネルギー消費量 & $\mathrm{O}$ & $x$ \\
\hline
\end{tabular}

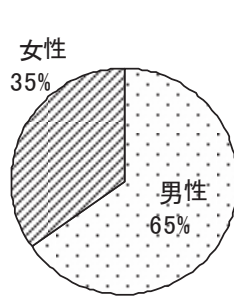

性別

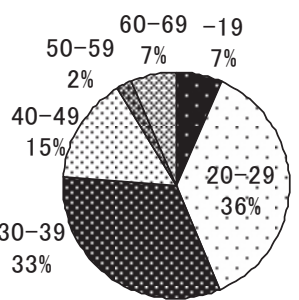

年齢

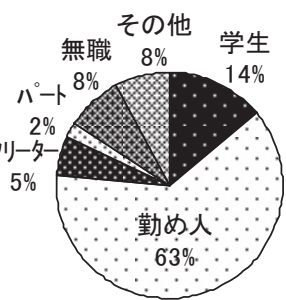

職業
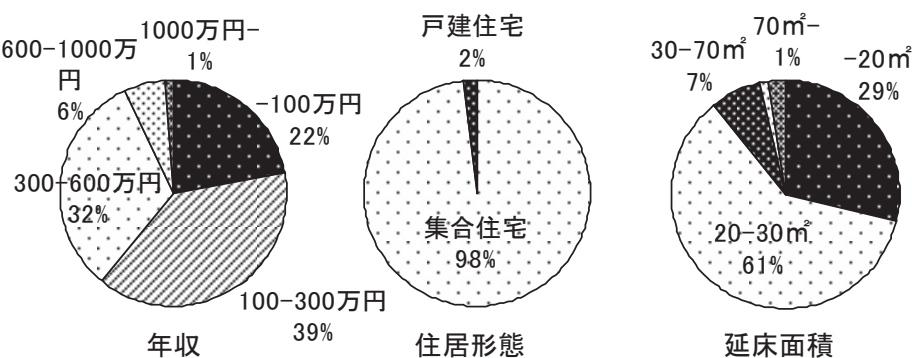

延床面積

図 1 回答世帯属性 $(n=858)$

\footnotetext{
*1 Assoc. Prof., Faculty of Science and Engineering, Waseda Univ., Dr. Eng.

*2 Graduate Student, Graduate School of Creative Science and Engineering, Waseda Univ.

* 3 Prof., Faculty of Life and Environmental Science, Kyoto Prefectural Univ., Dr. Eng.
} 


\section{3. 調査結果}

\section{1 年間エネルギー消費量}

本調查による単身世帯のエネルギー消費量の分布状況を図 2 に示す。 平均值 $14.5 \mathrm{GJ} /$ 年・世帯、中央值 $11.5 \mathrm{GJ} /$ 年・世帯に対し、標準偏差 は $7.7 \mathrm{GJ} /$ 年・世帯で大きくばらついている様子が分かる。年間エネル ギー消費量は特に $9.0 G J /$ 年・世帯に多く分布している。

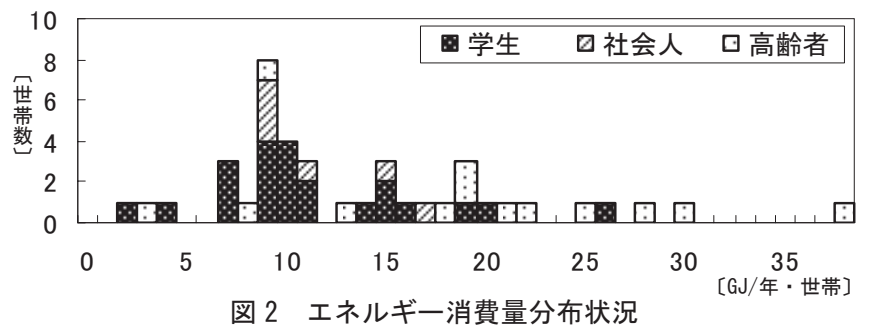

\section{2 生活行動時間のパターン分類}

本研究では、アンケート調査による全てのデータに対し分析を行っ た。生活行動時間に関して、典型的な平日における起床・外出・帰宅・ 就寝時刻を抽出した。その結果を 15 分間隔のタイムテーブルに变換 し、クラスタ分析による生活行動時間のパターン分類を行った。1 日 を 15 分 1 コマの 96 次元に変換し、外出・起床在宅・就寝在宅注 3$)$ の コマ数をパラメータとして、クラスタ分析を行い、以下の 4 パターン に分類した。

分類に用いるパラメータとしては、起床・外出・帰宅・就寝の時刻 などを併用することも考えられるが、エネルギー消費においては総在 宅時間が重要であると考え、本研究では時刻よりも時間による分類を 重視することとした。なお、サンプル数が 858 件と多いことから、今 回の分析には非階層的クラスタ分析を採用した。

(1) pattern 1『在宅タイプ』(117 世帯)

外出時間が 7 時間程度のグループで、昼間 9 時から 16 時まで外出 する世帯が多い。比較的外出時間の長い高齢者や学生が多く該当する。 (2) pattern 2『活動タイプ』(372 世帯)

外出時間が 10 時間程度のグループで、昼間 9 時から 19 時まで外出 する世帯が多い。社会人の中でも比較的早く帰宅する世帯である。

(3) pattern 3 『出不精タイプ』(43 世帯)

外出時間が 3 時間程度で、起床在宅時間が最も長い 14 時間程度の グループである。外出時間帯は世帯によってばらつきがあり、短時間 外出する高齢者や学生が比較的多く属している。

(4) pattern 4『多忙タイプ』(326 世帯)

外出時間が最も長く 14 時間程度で、起床在宅時間は最も短く 4 時 間程度のグループである。7 時から 21 時まで長時間外出する世帯が多 く、多忙な社会人が多い。

\section{3 使用家電機器のタイプ分類}

家電機器に関して、各機器の保有率に加え、1 週間あたりの使用頻 度を調查した。保有率注 4 )が $30 \%$ を超える家電機器を対象に、保有・ 使用頻度のタイプ分類を行った。まず、 1 週間あたりの使用回数・時 間を変数とし、ワード法によるクラスタ分析を行い、各対象機器に対 し非保有 (未使用) 0 ・使用頻度少 1 ・使用頻度多 2 の評価值を与えた。 さらに、その評価值をパラメータとし、非階層的クラスタ分析を行っ た。分類数を $3 \sim 10$ と変化させ、極端に該当数の少ないクラスタが存 在せず、各特長がはっきりした 4 分類を適切な分類数として決定した。
(1) type 1『質素タイプ』(241 世帯)

娛楽情報機器はほとんど保有せず、蝔房・家事衛生機器の保有率も 低い。さらに、厨房・家事衛生機器を保有していたとしても、それら の使用頻度は低いグループである。

(2) type 2『贅沢タイプ』(209 世帯)

娛楽情報機器、麀房・家事衛生機器ともに多く保有し、使用頻度も 高いグループである。DVD プレーヤー等の娛楽情報機器を多く使用し ている点が特徴である。

(3) type 3『娛楽タイプ』(188 世帯)

娛楽情報機器の使用頻度は高く、厨房・家事衛生機器は使用頻度が やや低めである。他のタイプに比ベパソコンの使用頻度が高いことが 特徴的であり、高齢者はほとんど属さない。

(4) type 4『家事タイプ』(220 世帯)

娛楽情報機器はほとんど保有せず、厨房・家事衛生機器は使用頻度 が高いグループである。特に、電気炊飯器の使用頻度が高く、自炊を している世帯が多い。

\section{4 ライフスタイルの分類}

エネルギー消費に関して、生活行動時間と家電機器の保有・使用状 況がライフスタイルを決定する要因であるとし、分類された生活行動 時間の pattern 1〜4 と使用家電機器の type 1〜4 をかけあわせるこ とで、16 分類されたライフスタイルを得た。図 3 にライフスタイルの 分類結果を示寸。全体として、社会人の占める割合が多いが、style 1,4,12 は高齢者の割合が多く、style 3, 7 は学生の割合が多い。

\section{4. ライフスタイルモデルの作成}

\section{1 生活行動時間の設定}

生活行動時間の調查より各ライフスタイルに対し、起床・外出・帰 宅・就寝時刻を抽出する。ここで 1 日を 15 分 1 コマの 96 次元に数值 化し、各コマに対して、外出・起床在宅・就寝在宅の行為を割り当て る。それぞれのライフスタイルにおける、各コマの最も高い行為者率 を算出し、その時刻(コマ)における行為を決定する。

\section{2 家電機器の設定}

はじめに、家電機器の保有状況を設定する。各ライフスタイルに対 し、娛楽情報機器の分野と欴房・家事衛生機器の分野に分類し、各分 野において保有率の高い機器から順に、保有・非保有を決定していく。 対象機器の保有率が $50 \%$ を越えたものを保有、超えないものを非保有 とした。まず、最もそのライフスタイルにおける保有率の高い機器を 決定する。さらに、決定した保有状況に該当する世帯において、次に 保有率の高い機器を決定するといった手順を踏む。

続いて家電機器の使用状況を設定寸る。保有とした各家電機器に対 し、該当世帯数が最も多い 1 週間あたりの使用日数を採用し、その使 用日数における 1 日にあたりの使用時間 (回数)の平均值を採用した。

\section{3 ライフスタイルモデルの作成}

設定した生活行動時間 - 保有家電機器の使用頻度を基に、性別 食事形態・入浴形態を考慮してライフスタイルモデルを作成する。 表 2 に 16 通りのライフスタイルモデルを示す。

\section{5. エネルギー消費量算出モデルの構築}

\section{1 エネルギー消費量算出モデルの構築}

図 4 にエネルギー消費量算出モデルの作成フローを示す。分類され 


\section{生活行動時間分類}

\section{pattern1『在宅タイプ』}

該当者数 117 [人]

外出

$7.15[\mathrm{~h} / \mathrm{day}]$

起床在宅

$9.55[\mathrm{~h} / \mathrm{day}]$

就寝在宅

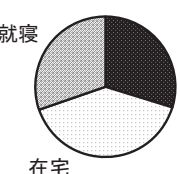

pattern2『活動タイプ』

該当者数 $372[人]$

外出

$10.70[\mathrm{~h} / \mathrm{day}]$

起床在宅

$6.61[\mathrm{~h} /$ day $]$

就寝在宅

$6.69[\mathrm{~h} / \mathrm{day}]$

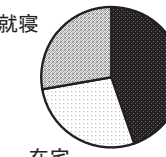

pattern3『出不精タイプ』

該当者数

外出

43 [人]

$3.19[\mathrm{~h} / \mathrm{day}]$

起床在宅

$3.93[\mathrm{~h} / \mathrm{day}]$

就寝在宅

$6.89[\mathrm{~h} / \mathrm{day}]$

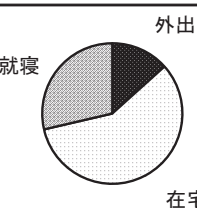

在宅

pattern4『多忙タイプ』

該当者数 326 [人]

外出

$13.63[\mathrm{~h} / \mathrm{day}]$

起床在宅

$4.13[\mathrm{~h} / \mathrm{day}]$ 在宅

就寝在宅 $6.25[\mathrm{~h} / \mathrm{day}]$

\section{使用家電機器分類}

\section{type1『質素タイプ』 \\ 多使用 2}

該当者数 241 [人]

テレビ・空調並

娛楽情報低

厨房·家事衛生低

\section{type2『贅沢タイプ』}

該当者数 209 [人]

テレビ·空調高

娛楽情報高

$\times$ 㕑房·家事衛生高

\section{type3『娛楽タイプ』}

該当者数 188 [人]

テレビ·空調

娛楽情報

厨房·家事衛生やや低

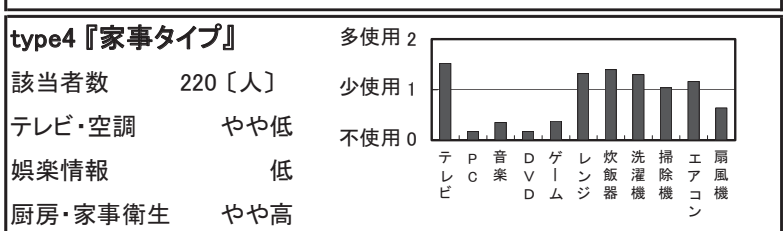

少使用 1

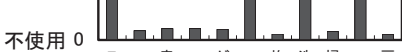

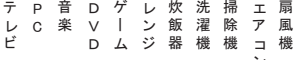

多使用 2

不使用 0 少使 1

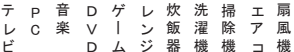

$=$

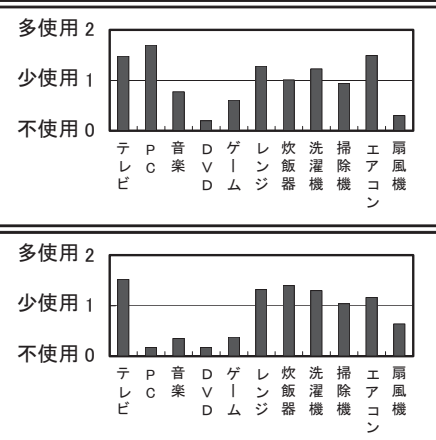

ライフスタイル分類

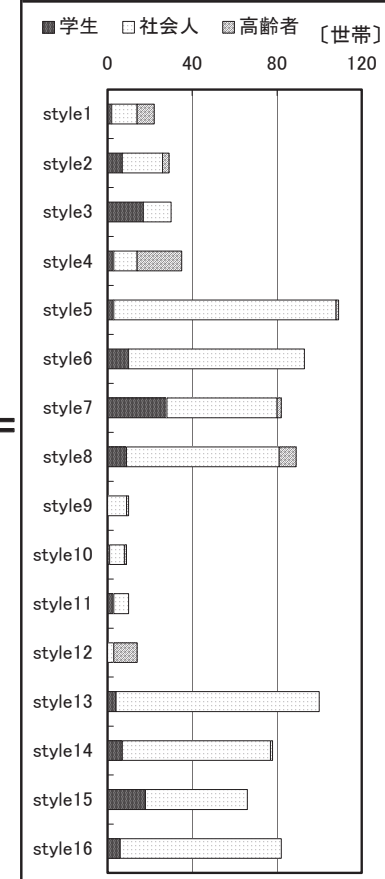

図 3 ライフスタイルの分類

表 2 ライフスタイルモデル

\begin{tabular}{|c|c|c|c|c|c|c|c|c|c|c|c|c|c|c|c|c|c|}
\hline \multicolumn{2}{|c|}{ ライフスタイル } & 1 & 2 & 3 & 4 & 5 & 6 & 7 & 8 & 9 & 10 & 11 & 12 & 13 & 14 & 15 & 16 \\
\hline \multicolumn{2}{|c|}{ 生活行動時間分類 } & 1 & 1 & 1 & 1 & 2 & 2 & 2 & 2 & 3 & 3 & 3 & 3 & 4 & 4 & 4 & 4 \\
\hline \multicolumn{2}{|c|}{ 使用家電機器分類 } & 1 & 2 & 3 & 4 & 1 & 2 & 3 & 4 & 1 & 2 & 3 & 4 & 1 & 2 & 3 & 4 \\
\hline \multirow{2}{*}{ 属性 } & 性別 & 男 & 女 & 男 & 女 & 男 & 男 & 男 & 男 & 男 & 女 & 女 & 女 & 男 & 男 & 男 & 男 \\
\hline & 職業 & 高齢者 & 学生 & 学生 & 高齢者 & 社会人 & 社会人 & 社会人 & 社会人 & 社会人 & 社会人 & 学生 & 高齢者 & 社会人 & 社会人 & 社会人 & 社会人 \\
\hline \multirow{4}{*}{$\begin{array}{l}\text { 生 } \\
\text { 活 } \\
\text { 行 } \\
\text { 動 } \\
\text { 時 } \\
\text { 間 } \\
\end{array}$} & 起床時刻 & $6: 45$ & $7: 00$ & $7: 30$ & $6: 30$ & 7:00 & $6: 45$ & 7:00 & $6: 30$ & 6:00 & $7: 30$ & $8: 00$ & $7: 00$ & $6: 30$ & $7: 00$ & $7: 00$ & $6: 30$ \\
\hline & 外出時刻 & $11: 00$ & $8: 30$ & 9:00 & $9: 30$ & $8: 00$ & $7: 45$ & $8: 00$ & $8: 00$ & 9:00 & 13:30 & $15: 00$ & $11: 30$ & $7: 00$ & $7: 30$ & $7: 45$ & 7:15 \\
\hline & 帰宅時刻 & 18:00 & $17: 00$ & $17: 00$ & $17: 00$ & 19:00 & 19:00 & $19: 00$ & $18: 30$ & $12: 00$ & $17: 00$ & 18:00 & $15: 00$ & $21: 00$ & $22: 00$ & $22: 00$ & $21: 00$ \\
\hline & 就寝時刻 & $24: 00$ & $25: 00$ & $25: 00$ & $23: 30$ & $24: 00$ & 24:00 & $24: 00$ & $24: 00$ & $23: 00$ & $24: 00$ & $25: 00$ & $23: 00$ & $24: 00$ & $24: 30$ & $25: 00$ & $24: 00$ \\
\hline \multirow{17}{*}{$\begin{array}{l}\text { 使 } \\
\text { 角 } \\
\text { 家 } \\
\text { 電 } \\
\text { 機 } \\
\text { 器 }\end{array}$} & 娛楽情報機器 & \multicolumn{16}{|c|}{ 使用日数/週 | 使用時間/日 } \\
\hline & テレビ & $7 \mid 5.5$ & $7 \mid 7.5$ & $7 \mid 6.5$ & $7 \mid 5.75$ & $7 \mid 5.0$ & $7 \mid 5.0$ & $7 \mid 5.0$ & $7 \mid 4.5$ & $7 \mid 8.5$ & $7 \mid 5.75$ & $7 \mid 5.0$ & $7 \mid 9.0$ & $7 \mid 3.5$ & $7 \mid 3.00$ & $7 \mid 3.25$ & $7 \mid 3.5$ \\
\hline & パソコン & $x$ & $x$ & $7 \mid 4.5$ & $x$ & $x$ & $7 \mid 4.0$ & $7 \mid 4.0$ & $x$ & $x$ & $7 \mid 2.0$ & $7 \mid 6.0$ & $x$ & $x$ & $7 \mid 2.50$ & $7 \mid 3.0$ & $x$ \\
\hline & 音楽プレーヤー & $x$ & $1 \mid 1.75$ & $7 \mid 2.5$ & $x$ & $x$ & $7 \mid 1.0$ & $7 \mid 2.5$ & $x$ & $x$ & $1 \mid 1.0$ & $1 \mid 2.0$ & $x$ & $x$ & $7 \mid 1.25$ & $7 \mid 3.0$ & $x$ \\
\hline & DVDプレーヤー & $x$ & $7 \mid 5.25$ & $x$ & $x$ & $x$ & $7 \mid 2.0$ & $x$ & $x$ & $x$ & $7 \mid 1.75$ & $x$ & $x$ & $x$ & $7 \mid 1.75$ & $x$ & $x$ \\
\hline & ゲーム機 & $x$ & $x$ & $1 \mid 1.0$ & $x$ & $x$ & $x$ & $3 \mid 3.0$ & $x$ & $x$ & $x$ & $x$ & $x$ & $x$ & $x$ & $x$ & $x$ \\
\hline & 厨房機器 & \multicolumn{16}{|c|}{ 使用目数/週 I 使用回数/目 } \\
\hline & 冷蔵庫 & 0 & 0 & 0 & 0 & 0 & 0 & 0 & 0 & 0 & 0 & 0 & $\mathrm{O}$ & 0 & 0 & 0 & 0 \\
\hline & 電子レンジ & $7 \mid 3$ & $7 \mid 3$ & $7 \mid 3$ & $7 \mid 3$ & $7 \mid 3$ & $7 \mid 3$ & $7 \mid 3$ & $7 \mid 3$ & $2 \mid 1$ & $7 \mid 2$ & $7 \mid 3$ & $7 \mid 2$ & $7 \mid 2$ & $7 \mid 2$ & $7 \mid 2$ & $7 \mid 2$ \\
\hline & オーブントースター & $x$ & $7 \mid 1$ & $x$ & $x$ & $x$ & $1 \mid 1$ & $x$ & $x$ & $x$ & $x$ & $1 \mid 1$ & $7 \mid 1$ & $x$ & $x$ & $x$ & $x$ \\
\hline & 電気炊飯器 & $x$ & $7 \mid 2$ & $3 \mid 1$ & $7 \mid 1$ & $x$ & $7 \mid 1$ & $1 \mid 1$ & $7 \mid 1$ & $x$ & $3 \mid 1$ & $3 \mid 1$ & $3 \mid 1$ & $x$ & $3 \mid 1$ & $1 \mid 1$ & $1 \mid 1$ \\
\hline & 電気ポツト & $x$ & $x$ & $x$ & $7 \mid 1$ & $x$ & $x$ & $x$ & $7 \mid 1$ & $x$ & $x$ & $x$ & $7 \mid 1$ & $x$ & $x$ & $1 \mid 1$ & $x$ \\
\hline & 家事衛生機器 & \multicolumn{16}{|c|}{ 使用目数/週 I 使用回数/目 } \\
\hline & 洗濯機 & $7 \mid 1$ & $7 \mid 1$ & $3 \mid 1$ & $3 \mid 1$ & $2 \mid 1$ & $3 \mid 1$ & $3 \mid 1$ & $3 \mid 1$ & $1 \mid 1$ & $2 \mid 1$ & $2 \mid 1$ & $7 \mid 1$ & $3 \mid 1$ & $3 \mid 1$ & $3 \mid 1$ & $2 \mid 1$ \\
\hline & 掃除機 & $x$ & $1 \mid 1$ & $1 \mid 1$ & $2 \mid 1$ & $x$ & $1 \mid 1$ & $1 \mid 1$ & $1 \mid 1$ & $x$ & $2 \mid 1$ & $1 \mid 1$ & $2 \mid 1$ & $x$ & $1 \mid 1$ & $1 \mid 1$ & $1 \mid 1$ \\
\hline & ドライヤー & $x$ & $7 \mid 1$ & $7 \mid 1$ & $7 \mid 1$ & $x$ & $7 \mid 1$ & $7 \mid 1$ & $7 \mid 1$ & $x$ & $7 \mid 1$ & $7 \mid 1$ & $x$ & $7 \mid 1$ & $7 \mid 1$ & $7 \mid 1$ & $7 \mid 1$ \\
\hline & アイロン & $x$ & $x$ & $x$ & $x$ & $x$ & $x$ & $x$ & $1 \mid 1$ & $x$ & $1 \mid 1$ & $x$ & $x$ & $x$ & $x$ & $x$ & $1 \mid 1$ \\
\hline 空調 & 冷暖房エアコン & $7 \mid 6.25$ & $7 \mid 9.75$ & $7 \mid 7$ & $7 \mid 6.5$ & $7 \mid 6.0$ & $7 \mid 7.5$ & $7 \mid 6.75$ & $7 \mid 5.5$ & $7 \mid 5.25$ & $7 \mid 9.25$ & $7 \mid 10.0$ & $7 \mid 7.25$ & $7 \mid 4.75$ & $7 \mid 6.0$ & $7 \mid 5.5$ & $7 \mid 5.25$ \\
\hline 入浴 & 入浴形態 & シャワー & シャワ- & シャワー & 風呂 & シャワー & シャワー & シャワー & シャワー & シャワー & 風呂 & 風呂 & $※$ & シャワー & シャワー & シャワ- & シャワー \\
\hline
\end{tabular}


たライフスタイルごとに生活行動時間、使用家電機器を決定し、16 通りのライフスタイルモデルを作成した。さらに、カタログ值 ${ }^{5}$ から 機器別エネルギー消費原単位を設定し、各ライフスタイルモデルと照 らし合わせることで、家電機器のエネルギー消費量、給湯の使用量を 算出する。また、算出された発熱スケジュールを動的熱負荷計算ソフ 卜 THERB ${ }^{6)}$ に入力し、冷暖房の熱負荷を計算した。エアコンにおける COP を冷房 5.1、暖房 5. $6^{5)}$ とし、空調のエネルギー消費量を得た。

図 5 に対象住宅モデルの平面図、表 3 に建物の設定条件を示す。床 面積 $23.2 \mathrm{~m}^{2}$ の単身世帯用集合住宅を標準モデルとし、中間階中間戸 とする。冷暖房設備として、洋室にエアコンが 1 台設置されている。

\section{2 エネルギー消費量算出モデルの検証}

図 6 にライフスタイルモデルごとのエネルギー消費量を示す。年間 エネルギー消費量の平均值は、 $11.2 \mathrm{GJ} /$ 年・世帯となり、ライフスタ イルごとの該当世帯数を考慮した平均值は、9.8GJ/年・世帯となった。 全てのライフスタイルを通して、給湯のエネルギー消費量が占める割 合が 4 割程度と最も多いが、空調のエネルギー消費量が占める割合は 1 割程度となっており、一般世帯に比べて空調の消費量の比率が小さ くなっている。また、style 12 においては、自宅で入浴を行わないラ イフスタイル設定であるため、㕌房におけるエネルギー消費量が最も 多くなった。style 4,10,11に関しては、一年中入浴時にお湯はりを するライフスタイル設定であるため、他のライフスタイルに比べ給湯 のエネルギー消費量が極めて多くなっており、年間エネルギー消費量 が 15.0GJ/年・世帯を超える結果となった。

また、在宅起床時間が長くなるほど、全体のエネルギー消費量が大 きくなる傾向にあり、それは照明に加え、娛楽情報のエネルギー消費 量が増加するためである。

\section{6. まとめ}

本研究では、単身世帯のライフスタイル実態を調查し、生活行動 時間と家電機器の使用状況をそれぞれ分類することで、単身世帯の ライフスタイルを 16 通りに分類した。また、それぞれの分類に合致 するライフスタイルモデルを作成し、モデル別に住宅内のエネルギ 一消費量を算出した。世帯構成の変化に伴い、4 人家族を対象とし た省エネルギー対策の検討のみでは不十分と考えられ、世帯人数每 のライフスタイルを考慮し、さらにライフスタイルのコントロール も含めたきめ細かい省エネルギー対策が必要である。本研究では在 宅時間が長いほどエネルギー消費量が多い結果となったが、本来は 外出時のエネルギー消費も考慮すべきであり、今後の課題である。

\section{謝辞}

本研究は、（財）トステム建材産業振興財団の助成、及び科研費 (18560576) の助成を受けて行ったものである。また、アンケート 調查にあたっては、(株) レオパレス 21 ブロードバンド事業部の協 力を得た。ここに記して感謝の意を表します。

注

注 1）L 社では、L 社管理の集合住宅に居住する世帯を対象に、テレビモニターを使用し たインターネットブロードバンドサービスを提供しており、ビデオ・オン・デマン ドやリモコンを使用したアンケート調查などが実施できる。

注2） 65 歳以上を高齢者、65 歳未満を若年者とした。さらに、若年者の中で、職業が高 校生・大学生であるものを学生、それ以外の若年者を職業に関わらず一括して社会 人として报った。

注3）自宅にいて、起床している行動を起床在宅、就寝している行動を就寝在宅とする。

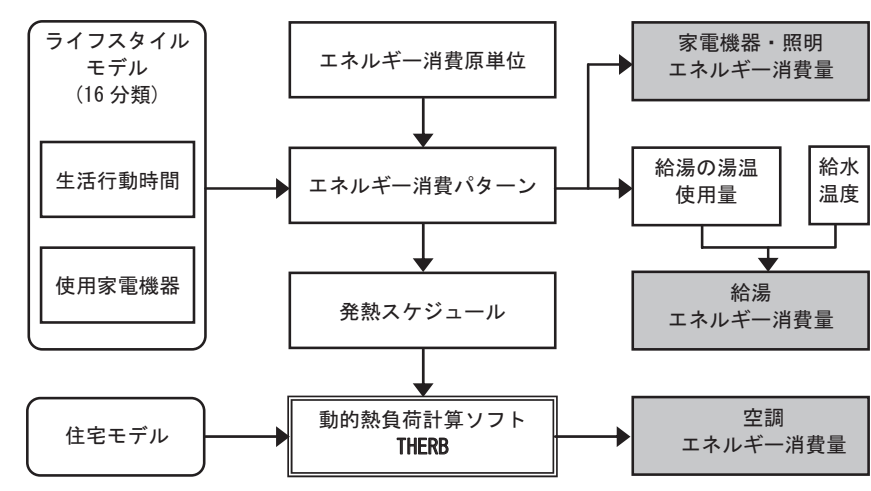

図 4 エネルギー消費量算出モデルの作成フロー

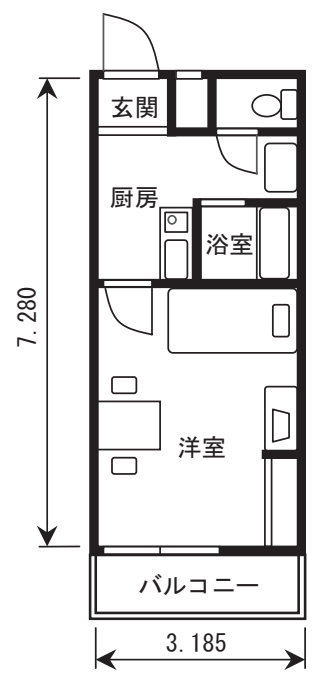

図 5 住宅モデルの平面図

表 3 建物の設定条件

\begin{tabular}{l|l}
\hline \multicolumn{1}{c|}{ 条件 } & \multicolumn{1}{|c}{ 入力項目 } \\
\hline 地域区分 & IV地域 \\
\hline 建物種別 & 集合住宅 \\
\hline 建物構造 & 木造 \\
\hline 住戸位置 & 中間階中住戸 \\
\hline 床面積 & $23.2 \mathrm{~m}^{2}$ \\
気密性能 & 0.5 回/h(換気量にて反映) \\
\hline 旦射遮蔽 & 庇(上階バルコニー) \\
空ガラス & 単層ガラス \\
\hline 冷暖房設備 & 洋室(1台) \\
\hline 建物モデル & L社汎用集合住宅 \\
\hline \multicolumn{1}{c}{$\mathbf{N}$} &
\end{tabular}

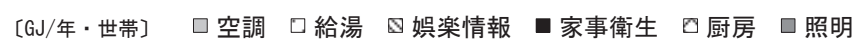

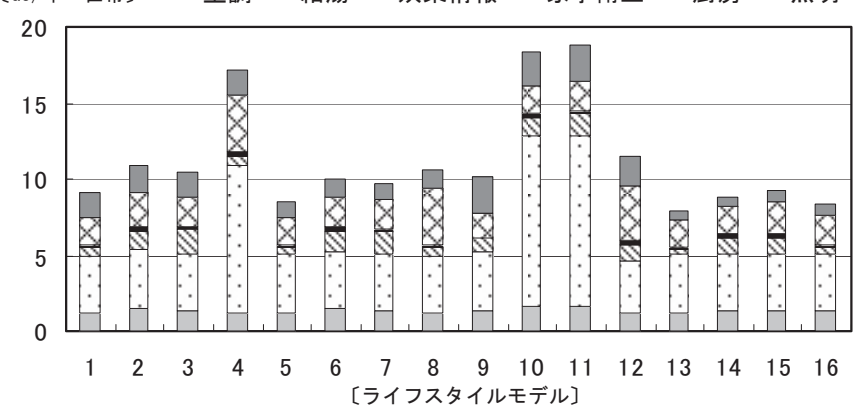

図 6 ライフスタイルモデルとエネルギー消費量

注4）実際に使用しているか否かに関わらず、対象機器を所持している事を「保有」とし、 以下のように定義した。

$$
\text { 保有率 }=\frac{\text { 対象機器を保有している世帯 }}{\text { 全単身世帯 }}
$$

\section{参考文献}

国立社会保障・人口問題研究所 : 日本の世带数の将来推計(全国推計)、2003 年 住環境計画研究所 : 家庭用エネルギー統計年報、2005 年度版

謝静超ら : 低負荷型ライフスタイルの省エネ効果に関する調査研究その 1 ～6、日 本建築学会大会学術講演梗概集、pp295-303、2004 年 8 月

湯淺和博 : 単身世帯における省エネライフスタイルの効果(その3)、日本建築学会 大会学術講演梗概集、pp389-390、2004 年 8 月

省エネルギーセンター : 省エネ性能カタログ、2007 年 6 月

6) Ozaki A., Tsujimaru T. : Prediction of Hygrothermal Environment of Buildings Based upon Combined Simulation of Heat and Moisture Transfer and Airflow, Journal of the International Building Performance Simulation Association, Vol. 16 , No. 2, pp. 30-37, 2006

[2008年 2 月20日原稿受理 2008年 4 月 1 日採用決定］ 